\title{
Common metabolic health problems among women
}

\author{
Sununta Youngwanichsetha* \\ Department of Maternal-Newborn Nursing and Midwifery, Faculty of Nursing, Prince of Songkla \\ University, Hat Yai, Songkhla, Thailand
}

\begin{abstract}
Received: 12 February, 2020
Accepted: 05 June, 2020

Published: 06 June, 2020

*Corresponding author: Sununta Youngwanichsetha, $\mathrm{PhD}$, Department of Maternal-Newborn Nursing and Midwifery, Faculty of Nursing, Prince of Songkla University, Hat Yai, Songkhla, Thailand, E-mail: sununta.y@psu.ac.th
\end{abstract}

Keywords: Metabolic health; Women health

https://www.peertechz.com

\section{Check for updates}

Metabolic health is defined as physical conditions that involve metabolic functions and its associated health impacts. Metabolism is the process occurring in the cells in order to get energy and remove waste products. Understanding of metabolism is the basis of improving metabolic health and prevention of metabolic health problems and its associated complications. Metabolism includes catabolism and anabolism.

Catabolism is the metabolism process of breaking large molecules of nutrients into smaller molecules in order to produce biochemical energy, adenosine triphosphate (ATP). It occurs in digestive system and human body cells. Carbohydrate, protein, and lipids are engaged catabolic metabolism through the process of glycolysis, Kreb's cycle and citric acid cycle in mitochondria and cytosol. Examples of catabolism are oxidation of glucose or fatty acid as a source of energy. Many hormones act as signals to control catabolism [1-3]. The catabolic hormones include adrenaline, glucagon, cortisol, melatonin, hypocretin, cytokines. Catabolic exercise is any types of aerobic exercise which can burn glycogen, fat or proteins that may come from muscle.

Anabolism is the metabolic process that builds complex molecules from simpler ones. It is composed of biochemical reactions that require an input of ATP for energy. Anabolic reactions in biosynthesis use the process of condensation and reductions. Anabolic processes require hormones including insulin, steroids and cofactors including vitamins, minerals $[4,5]$. Examples of anabolism are: 1) simple sugars combine to form polysaccharides, 2) glycerol reacts with fatty acids to make lipids, and 3) amino acids join together to form proteins. Anabolic exercise such as weight lifting can build muscle mass and its strength. Therefore, metabolic health requires essential energy supply and expenditure for daily life activities, physical and mental health.
Women worldwide experience many metabolic health problems including obesity, hyperglycemia, dyslipidemia, insulin resistance, hyperinsulinemia, and its consequences. Example of common metabolic health problems are polycystic ovary syndrome (PCOS), gestational diabetes mellitus (GDM), prediabetes, type 2 diabetes, metabolic syndrome, hypertensive disorders, non-alcoholic fatty liver disease (NAFAD), hyperthyroidism and hypothyroidism. Women with PCOS are more likely to have sub-infertility or infertility due to hyperandrogenism and anovulation. Women with insulin resistance experience GDM and hypertensive disorders during pregnancy. Women with a history of GDM develop prediabetes, type 2 diabetes, and metabolic syndrome in their later life. NAFLD is more common in women with overweight and obesity [5-8]. Hyperthyroidism and hypothyroidism are observed in women with metabolic health problems. Cardiovascular and kidney diseases are also common complications. These metabolic health problems result in shortening life expectancy among women and developing many chronic diseases leading to poor quality of life and immature death.

These manifestations are cumulative of its pathogenesis from childhood to adulthood. Therefore, metabolic health promotion should be educated and advised across the lifespan. Health literacy on dietary pattern and regular exercise is the main focus. Effective modification to avoid overconsumption of sugar, high-fructose corn syrup, trans fat and nimal fat should be clearly recommended for all in order to prevent hyperglycemia, dyslipidemia, and insulin resistance. Wisely choosing healthier foods items containing complex carbohydrate, essential amino acids, fatty acids, vitamins and antioxidants are important to maintain mitochondrial function, prevent oxidative stress, and promote anabolism. Finally, doing enjoyable exercise should be encouraged among women in order to enhance insulin sensitivity, catabolism process and metabolic health. 


\section{References}

1. Awlaqi AA, Alkhayat $K$, Hammadeh ME (2016) Metabolic syndrome and infertility in women. International Journal of Women's Health and Reproduction Sciences 4: 89-95. Link: https://bit.ly/30bnSYk

2. Belan M, Harnois-Leblane S, Laferrere B, Baillargeo JP (2018) Optimizing reproductive health in women with obesity and infertility. CMAJ 24: E742-E745. Link: https://bit.ly/2AK8reJ

3. Dennett CC, Simon J (2015) The role of polycystic ovary syndrome and metabolic health: overview and approaches for treatment. Diabetes Spectr 28: 116-120. Link: https://bit.ly/2Y3J2F1

4. Fontana R, Torre SD (2016) The deep correlation between energy metabolism and reproduction: A view on the effects of nutrition for women fertility. Nutrients 8: 87. Link: https://bit.ly/3cEdj2m
5. Huang G, Coviello A (2012) Clinical update on screening, diagnosis and management of metabolic disorders and cardiovascular risk factors associated with polycystic ovary syndrome. Curr Opin Endocrinol Diabetes Obes 19: 512-519. Link: https://bit.ly/3eMK9Q6

6. Kravitz HM, Kazlauskaite R, Joffe H (2018) Sleep, health and metabolism in midlife women and menopause Obstet Gynecol Clin North Am 45: 679-694. Link: https://bit.ly/2Mzrds9

7. Mu L, Zhao Y, Li R, Lai Y, Chang HM, et al. (2018) Prevalence of polycystic ovary syndrome in a metabolically healthy obese population. Int $\mathrm{J}$ Gynaecol Obstet 146: 164-169. Link: https://bit.ly/2UdjleO

8. Shah D, Rasool S (2016) Polycystic ovary syndrome and metabolic syndrome: the worrisome twosome? Climacteric J 9: 7-16. Link: https://bit.ly/375AVvy
Discover a bigger Impact and Visibility of your article publication with Peertechz Publications

\section{Highlights}

* Signatory publisher of ORCID

* Signatory Publisher of DORA (San Francisco Declaration on Research Assessment)

* Articles archived in worlds' renowned service providers such as Portico, CNKI, AGRIS, TDNet, Base (Bielefeld University Library), CrossRef, Scilit, J-Gate etc.

* Journals indexed in ICMJE, SHERPA/ROMEO, Google Scholar etc.

- OAI-PMH (Open Archives Initiative Protocol for Metadata Harvesting)

* Dedicated Editorial Board for every journal

* Accurate and rapid peer-review process

* Increased citations of published articles through promotions

* Reduced timeline for article publication

Submit your articles and experience a new surge in publication services

(https://www.peertechz.com/submission).

Peertechz journals wishes everlasting success in your every endeavours.

Copyright: () 2020 Youngwanichsetha S. This is an open-access article distributed under the terms of the Creative Commons Attribution License, which permits unrestricted use, distribution, and reproduction in any medium, provided the original author and source are credited. 